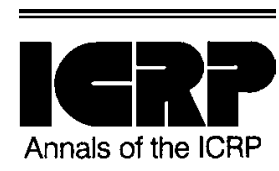

\title{
The History of ICRP and the Evolution of its Policies
}

\author{
R.H. Clarke and J.Valentin
}

\section{Invited by the Commission in October 2008}

\begin{abstract}
Within 12 months of the discovery of X rays in 1895, papers appeared in the literature reporting adverse effects from high exposure. In 1925, the first International Congress of Radiology, held in London, considered the need for a protection committee, which it established at its second congress in Stockholm in 1928. This paper celebrates the $80^{\text {th }}$ anniversary of ICRP by tracing the history of the development of its policies, and identifying a few of the personalities involved from its inception up to the modern era. The paper follows the progress from the early controls on worker doses to avoid deterministic effects, through the identification of stochastic effects, to the concerns about public exposure and increasing stochastic risk estimates. The key features of the recommendations made by ICRP from 1928 up to the most recent in 2007 are identified.
\end{abstract}

(c) 2009 ICRP. Published by Elsevier Ltd.

Keywords: Occupational exposure; Public exposure; Medical exposure; Stochastic; Deterministic 



\section{INTRODUCTION}

\subsection{Sources}

(1) This paper is based primarily on Clarke's (2008) presentation at the XII Congress of the International Radiation Protection Association (IRPA) and on a previous article by Clarke and Valentin (2005). It also draws extensively from Lindell (1996a). Additional sources include Lindell (1996b, 1999, 2003) and Taylor (1979). Valuable suggestions were provided by Clement (2009).

\subsection{The discovery of radiation and its associated hazards}

(2) Röntgen discovered X rays in November 1895 (Röntgen, 1895). Just a few months later, X-ray dermatitis was observed in the USA (Grubbé, 1933). Similar observations soon occurred in several countries; for instance, Drury (1896) described radiation damage to the hands and fingers of early UK experimental investigators, and Leppin (1896) made a similar report concerning German observations.

(3) Becquerel's (1896) identification of radioactivity, and the subsequent discovery of radium (Curie, 1898), led to many further cases of radiation damage, but the idea of inflicting such damage at will on selected tissues also paved the way for radiation therapy. The first proven cures of cancer patients were by Sjögren and Stenbeck in Sweden in 1899 (Mould, 1993).

(4) X rays were used by military field hospitals as early as 1897 (Churchill, 1898), although the number of X-ray injuries escalated during the Great War when primitive mobile X-ray equipment was used in the field. In the next 10 years, many papers were published on the tissue damage caused by radiation. However, during the first two decades following the discovery of $\mathrm{X}$ rays and radium, ignorance about the risks caused numerous injuries. Apparently, early radiologists often used their own hands to focus the beam of their X-ray machines, and skin cancer as a direct result of such exposure was described within 6 years of Röntgen's discovery (Frieben, 1902).

(5) The deleterious effects on hands and skin could be gruesome (as evidenced by the amputated hand of the German radiologist Professor Paul Krause at the Deutsches Röntgenmuseum in Remscheid). Unfortunately, it soon turned out that effects could be lethal, and the well-known monument to 'X-ray and radium martyrs' in Hamburg, erected in 1936 by the German Röntgen Society, names several hundred medical workers of many nationalities who died from radiation damage (Molineus et al., 1992).

\subsection{The first protection recommendations}

(6) Just 1 year after Röntgen's discovery of X rays, the American engineer Wolfram Fuchs (1896) gave what is generally recognised as the first protection advice. This was: 
- make the exposure as short as possible;

- do not stand within 12 inches $(30 \mathrm{~cm})$ of the X-ray tube; and

- coat the skin with Vaseline (a petroleum jelly) and leave an extra layer on the most exposed area.

Thus, within 1 year of dealing with radiation, the three basic tenets of practical radiological protection - time, distance, and shielding - had been established!

(7) In the early $1920 \mathrm{~s}$, radiation protection regulations were prepared in several countries, but it was not until 1925 that the first International Congress of Radiology (ICR) took place and considered establishing international protection standards.

\subsection{The International Commission on Radiological Protection}

\subsubsection{Its gestation and birth as IXRPC}

(8) When the first ICR was held in London in 1925, the most pressing issue was that of quantifying measurements of radiation, and the International Commission on Radiation Units and Measurements (ICRU) was created, although it was then named the 'International X-ray Unit Committee'. The need for an international radiological protection committee was discussed, and the task was to ensure that a number of physicists interested in radiation protection would be present at the next ICR.

(9) The second ICR was held in Stockholm in 1928 and ICRU proposed the adoption of the röntgen unit; an event which was noted with far more interest than the birth of what is now ICRP under the name of the 'International X-ray and Radium Protection Committee' (IXRPC). As a courtesy to the host country, Rolf Sievert (who was then 32 years old) was named Chairman, but the driving person was George Kaye of the British National Physics Laboratory (Sievert, 1957; Lindell, 1996a). The other members present included Lauriston Taylor from the US National Bureau of Standards and Val Mayneord from the UK, who were in their 20 s at the time. There were only two medical doctors on the Committee (Lindell, 1996a).

\subsubsection{Development into maturity}

(10) Before the Second World War, the Committee (or Commission, as it was called from 1934) was not active between the ICRs, and met for just 1 day at the ICRs in Paris in 1931, Zürich in 1934, and Chicago in 1937.

(11) Lindell (1996a) noted that at the 1934 meeting in Zürich, the Commission was faced with undue pressures; the hosts insisted on four Swiss participants (out of a total of 11), and the German authorities replaced the Jewish German member with another person. In response to these pressures, the Commission decided on new rules in order to establish full control over its future membership.

(12) After the Second World War, the first post-war ICR convened in London in 1950. Just two of the members of IXRPC had survived the war, namely Lauriston Taylor and Rolf Sievert. Taylor was invited to revive and revise the Commission, 
which was now given its present name: the International Commission on Radiological Protection (ICRP). Sievert remained an active member, Sir Ernest Rock Carling (UK) was appointed as Chairman, and Taylor was Acting Secretary; after the ICR, Walter Binks (UK) took over as Scientific Secretary because of Taylor's concurrent involvement with the sister organisation, ICRU.

(13) At the 1950 meeting, a new set of rules was drafted, quite similar to the present rules, for the work of ICRP and the selection of its members (ICRP, 1951), and six sub-committees were established on:

- permissible dose for external radiation;

- permissible dose for internal radiation;

- protection against $X$ rays generated at potentials up to 2 million volts;

- protection against $X$ rays above 2 million volts, and $\beta$ rays and $\gamma$ rays;

- protection against heavy particles, including neutrons and protons; and

- disposal of radioactive wastes and handling of radioisotopes.

(14) It was also proposed (ICRP, 1951) that the Commission should 'recommend that all interested countries establish, each for itself, a central national committee to deal with problems of radiation protection - such a central committee to have sub-committees matching those of the International Commission on Radiological Protection as closely as their circumstances permit. So far as possible, members of the international sub-committees should be selected from the corresponding subcommittees of the various national committees. On matters of policy and formal agreements, communication will be from the central national committee to the International Commission. It is, however, recommended that direct communication on technical matters may be conducted between the corresponding national and international sub-committees'.

(15) This idea of a hierarchy of national and international committees and commissions, which never came into fruition, appears to herald Sievert's later visions of expanding ICRP into a single international authority, taking on the roles of the United Nations Scientific Committee on the Effects of Atomic Radiation (UNSCEAR) and other intergovernmental international organisations in radiation sciences and radiological protection (Lindell, 1999).

(16) However, it was now obvious that the amount of work expected from ICRP vastly exceeded what could be achieved by a handful of people meeting only in connection with the ICRs. An informal meeting was held at a radiobiology conference in Stockholm in 1952. The next formal meeting of ICRP took place at the seventh ICR in Copenhagen in 1953, and at that occasion, it was planned that the sub-committees proposed in 1950 would meet a week before the actual ICR started. However, since no member of the originally proposed Sub-Committee V on heavy particles was able to participate in Copenhagen, this was merged into SubCommittee IV on other high-energy radiations. The original Sub-Committee VI failed to produce any report at the time, but was retained, now as Sub-Committee V. All sub-committee chairmen were members of the Commission. Thus, the structure used in 1953 was (ICRP, 1955): 
SC I: Permissible doses for external radiation;

SC II: Permissible doses for internal radiation;

SC III: Protection against $X$ rays generated at potentials up to three million volts;

SC IV: Protection against $X$ rays above three million volts, $\beta$ rays, $\gamma$ rays, and heavy particles, including neutrons and protons; and

SC V: Handling and disposal of radioactive isotopes.

(17) The Commission and its committees (as they were now called) met again in the spring of 1956 in Geneva. This was the first time that a formal meeting of the Commission took place at a venue other than an ICR (the 1956 ICR was in Mexico, but ICRP simply could not afford to participate there). At this meeting, ICRP became formally affiliated with the World Health Organization (WHO) as a "participating non-governmental organisation'. In 1959, a formal relationship had also been established with the International Atomic Energy Agency (IAEA), and various forms of relations were also in place with UNSCEAR, the International Labour Office (ILO), the Food and Agriculture Organization (FAO), the International Organization for Standardization (ISO), and the United Nations Educational, Scientific, and Cultural Organization.

(18) In the 1950s, the Commission did not have an administrative or financial basis commensurate with its increasing workload. Almost no funds were available to cover travelling costs, so members participated in meetings to the extent that they were able to obtain funding in their own countries (or if they could finance their participation with personal funds, as Sievert seems to have done on some occasions). Furthermore, until 1957, the Secretary of the Commission was simply one of the members who had accepted this as an honorary position. In 1957, the then Secretary, Walter Binks, had to retire for health reasons, and Bo Lindell (who was not a member of the Commission at the time) was first asked to be a 'temporary' secretary, then went on to become the Scientific Secretary, but still unpaid. Minor contributions had been received from the International Society of Radiology (ISR) from the National Association of Swedish Insurance Companies, and from 'private Swedish sources' (almost certainly, Sievert); some ad-hoc financing of meetings with UNSCEAR was also received directly from UNSCEAR.

(19) However, in 1960 , the Ford Foundation provided a grant of $\$ 250,000$ to ICRP, a very significant amount at the time, which meant that some funds were now available for secretariat and travelling and meeting costs. In the period 1960 1963, further grants totalling \$60,000 were received from WHO, ISR, UNSCEAR, and IAEA, and the concept of grant applications and funding thus became established.

(20) The first full-time, paid Scientific Secretary of ICRP was F. David Sowby, who replaced Bo Lindell at the eighth ICR in Montreal, 1962. Sowby lived in Canada at the time, but moved to England where the new Chairman, Sir Edward ('Bill') Pochin, was based. The Secretariat was established at Sutton in Surrey, and the presence of a full-time employee greatly improved the efficiency of the work of ICRP. 


\subsubsection{2-2005: a modern structure}

(21) At a meeting in Stockholm in May 1962, the Commission also decided to reorganise the committee system in order to improve productivity, which had differed considerably between committees. The five 'Roman numeral' committees were replaced with four committees with Arabic numerals, rather similar to the present Committees 1-4:

C1: Radiation effects;

C2: Internal exposure;

C3: External exposure; and

C4: Application of recommendations.

It was decided that the new committees should watch the development within various fields, and make suggestions on necessary actions to the Commission. Reports, however, should not be drafted by the committees but by ad-hoc task groups. The drafts would then be reviewed by the relevant committee before adoption by the Commission.

(22) However, even though the committees had been re-organised, several further reports were published under the banner of the earlier 'Roman numeral' committees, ending with Publication 5 (ICRP, 1965) which was a report by Committee V on handling and disposal of radioactive isotopes. ${ }^{1}$

\section{Defining the formal tasks of the Committees}

(23) During the 1977-1981 term, the Commission reviewed and updated the names and missions of its committees. Increasing attention to organisational formalities can be seen in the fact that beginning in 1977, mission statements for each committee were published in leaflets describing ICRP. In the 1977 leaflet, Committee 1 retained (as it still does) its name, 'Radiation effects'. Its mission was given as follows: 'Committee 1 will assess the risk and severity of stochastic effects and the induction rates of the non-stochastic effects of irradiation. It will consider the modifying influence of exposure parameters such as dose rate, fractionation of dose, RBE, spatial distribution of dose and any synergistic effects of chemical and physical factors'. From 1981, the tense was amended: 'Committee 1 assesses. ..', 'It considers. .' but otherwise the description remained unchanged until 1998 (see below).

(24) However, Committee 2 was no longer named 'Internal exposure'; in 1977, its name was changed to 'Secondary limits' and its mission statement was: 'The basic function of Committee 2 is to develop values of secondary limits, based on the Commission's recommended dose-equivalent limits. For the immediate future the committee will be fully concerned with the preparation of secondary limits for internal irradiation; because of this, matters to do with the derivation of secondary limits for external irradiation will, for the time being, be considered by Committee 3'.

\footnotetext{
${ }^{1}$ The sponsoring committee is given a Roman numeral in some later reports, but these instances simply reflect inconsistent copy-editing; i.e. those reports were really sponsored by the new 'Arabic numeral' committees.
} 
(25) In 1981, the word 'fully' disappeared. In 1985, the description was abbreviated: 'Committee 2 develops values of secondary limits for internal and external irradiation, based on the Commission's recommended primary limits on dose equivalent'. At that time, Committee 2 had essentially completed the huge Publication 30 on intake limits for workers, in three parts and four supplements plus a separate index issue, i.e. eight separate books comprising 26 standard issues of Annals of the ICRP (ICRP, 1979a,b, 1980, 1981, 1982a,b,c,d). An addendum constituting a fourth and final part appeared as ICRP (1989). Thus, it was considered that the work of Committee 2 on internal radiation had advanced far enough to permit the Committee to include, as originally intended, external irradiation in its scope. The name and the 1985 description remained unchanged until 1998.

(26) The new name given to Committee 3 in 1977, 'Protection in medicine' (which is still valid today), reflected a significant re-orientation of priorities. The mission was stated in 1977 as follows: 'The Commission considers that its relationship to the International Congress of Radiology and its traditional contacts with the medical profession warrant the establishment of a committee specifically concerned with radiation protection in medicine. Matters requiring particular attention by the committee include protection of the patient in radiodiagnosis and radiotherapy

Table 1.1. Names and mission statements of the ICRP committees.

\begin{tabular}{|c|c|c|}
\hline Committee number & Committee name & Mission statement \\
\hline Committee 1 & Radiation effects & $\begin{array}{l}\text { Committee } 1 \text { considers the risk of induction of cancer and } \\
\text { heritable disease (stochastic effects) together with the } \\
\text { underlying mechanisms of radiation action; also, the risks, } \\
\text { severity, and mechanisms of induction of tissue/organ } \\
\text { damage and developmental defects (deterministic effects). }\end{array}$ \\
\hline Committee 2 & $\begin{array}{l}\text { Doses from } \\
\text { radiation exposure }\end{array}$ & $\begin{array}{l}\text { Committee } 2 \text { is concerned with development of dose } \\
\text { coefficients for the assessment of internal and external } \\
\text { radiation exposure, development of reference biokinetic } \\
\text { and dosimetric models, and reference data for workers and } \\
\text { members of the public. }\end{array}$ \\
\hline Committee 3 & Protection in medicine & $\begin{array}{l}\text { Committee } 3 \text { is concerned with protection of persons and } \\
\text { unborn children when ionising radiation is used for } \\
\text { medical diagnosis, therapy, or for biomedical research; } \\
\text { also, assessment of the medical consequences of accidental } \\
\text { exposures. }\end{array}$ \\
\hline Committee 4 & $\begin{array}{l}\text { Application of the } \\
\text { Commission's } \\
\text { recommendations }\end{array}$ & $\begin{array}{l}\text { Committee } 4 \text { is concerned with providing advice on the } \\
\text { application of the recommended system of protection in all } \\
\text { its facets for occupational and public exposure. It also acts } \\
\text { as the major point of contact with other international } \\
\text { organisations and professional societies concerned with } \\
\text { protection against ionising radiation. }\end{array}$ \\
\hline Committee 5 & $\begin{array}{l}\text { Protection of the } \\
\text { environment }\end{array}$ & $\begin{array}{l}\text { Committee } 5 \text { is concerned with radiological protection of } \\
\text { the environment. It aims to ensure that the development } \\
\text { and application of approaches to environmental } \\
\text { protection are compatible with those for radiological } \\
\text { protection of man, and with those for protection of the } \\
\text { environment from other potential hazards. }\end{array}$ \\
\hline
\end{tabular}


and protection in nuclear medicine. Committee 3 will temporarily be concerned with the development of secondary standards for external radiation'.

(27) In 1985, the last sentence about secondary standards for external radiation was removed, since that task had now been assigned to Committee 2. Also, the penultimate sentence was amended as follows: '. . . include protection of the patient and worker in radiodiagnosis, radiotherapy and nuclear medicine'.

(28) In the 1977 revision, Committee 4 kept its old name, 'Application of the Commission's recommendations', which is still valid today, and its mission was stated as follows: 'Committee 4 will continue its role of providing advice on the Commission's system of dose limitation, and on protection of the worker and the public. The committee will also serve as a major point of contact with international organisations concerned with radiation protection'. From 1981, the tense was amended: 'The Committee provides advice on the application of the Commission's. . ', 'It also serves...', but otherwise the description remained unchanged until 1998.

(29) In 1998, the Commission re-reviewed the entire set of names and mission statements. The name of Committee 2 was changed again, from 'Secondary limits' to its present version, 'Doses from radiation exposure'. The mission statements of all of the committees were updated at the same time (see Table 1.1).

Table 1.2. The officers of the Commission and its committees.

\begin{tabular}{lll}
\hline Position & Term & Name \\
\hline IXRPC/ICRP and & $1928-1931$ & Rolf Sievert, Sweden \\
Main Commission & $1931-1937$ & René Ledoux-Lebard, France \\
Chair & $1937-1950$ & Lauriston S. Taylor, USA \\
& $1950-1956$ & Sir Ernest Rock Carling, UK \\
& $1956-1962$ & Rolf Sievert, Sweden \\
& $1962-1969$ & Sir Edward Eric ('Bill') Pochin \\
& $1969-1977$ & C. Gordon Stewart, Canada \\
$1977-1985$ & Bo Lindell, Sweden \\
$1985-1993$ & Dan J. Beninson, Argentina \\
$1993-2005$ & Roger H. Clarke, UK \\
Scientific Secretary & $2005-2009$ & Lars-Erik Holm, Sweden \\
& $2009-$ & Claire Cousins, UK \\
1928 & George W.C. Kaye, UK \\
& 1934,1937 & Lauriston S. Taylor, USA \\
& $1947-1950$ & Lauriston S. Taylor, USA \\
$1950-1955$ & Walter Binks, UK \\
1956 & Eric E. Smith, UK \\
$1957-1962$ & Bo Lindell, Sweden \\
$1962-1985$ & F. David Sowby, Canada \\
$1985-1987$ & Michael ('Mike') C. Thorne, UK \\
$1987-1997$ & Hylton Smith, UK \\
$1997-2008$ & Jack Valentin, Sweden \\
& $2009-$ & Christopher H. Clement, Canada \\
\hline
\end{tabular}


Table 1.3. The officers of the committees of ICRP.

\begin{tabular}{|c|c|c|}
\hline Position & Term & Name \\
\hline \multirow[t]{2}{*}{ SC I / C I Chair } & $1950-1959$ & Giaocchino Failla, USA \\
\hline & $1959-1962$ & John F. Loutit, UK \\
\hline SC II / C II Chair & $1950-1962$ & Karl Z. Morgan, USA \\
\hline SC III / C III Chair & $1950-1962$ & Robert G. Jaeger, Austria \\
\hline \multirow[t]{3}{*}{ SC IV / C IV Chair } & $1950-1956$ & W. Valentine Mayneord, UK \\
\hline & $1956-1959$ & Harold E. Johns, Canada \\
\hline & $1959-1962$ & Gerard James Neary, UK \\
\hline \multirow[t]{3}{*}{ SC V / C V Chair } & $1950-1953$ & Dean B. Cowie, USA \\
\hline & $1953-1956$ & André J. Cipriani, Canada \\
\hline & $1956-1962$ & Conrad P. Straub, USA \\
\hline SC VI Chair & $1950-1953$ & Herbert M. Parker, UK \\
\hline \multirow[t]{7}{*}{ Committee 1 Chair } & $1962-1965$ & John F. Loutit, UK \\
\hline & 1965-1973 & Howard B. Newcombe, Canada \\
\hline & $1973-1981$ & Arthur C. Upton, USA \\
\hline & $1981-1985$ & Dan J. Beninson, Argentina \\
\hline & 1985-2001 & Warren K. Sinclair, USA \\
\hline & 2001-2009 & Roger Cox, UK \\
\hline & $2009-$ & Ohtsura Niwa, Japan \\
\hline \multirow[t]{6}{*}{ Committee 2 Chair } & $1962-1973$ & Karl Z. Morgan, USA \\
\hline & $1973-1985$ & Jack Vennart, UK \\
\hline & 1985-1993 & Charles ('Charlie') B. Meinhold, USA \\
\hline & $1993-2001$ & Alexander Kaul, Germany \\
\hline & $2001-2007$ & Christian Streffer, Germany \\
\hline & $2007-$ & Hans-Georg Menzel, Switzerland \\
\hline \multirow[t]{8}{*}{ Committee 3 Chair } & $1962-1965$ & Eric E. Smith, UK \\
\hline & 1965-1977 & Bo Lindell, Sweden \\
\hline & $1977-1985$ & Charles B. Meinhold, USA \\
\hline & 1985-1993 & Julian Liniecki, Poland \\
\hline & 1993-1996 & Henri Jammet, France \\
\hline & 1996-2005 & Fred J. Mettler, USA \\
\hline & 2005-2009 & Claire Cousins, UK \\
\hline & $2009-$ & Eliseo Vañó, Spain \\
\hline \multirow[t]{7}{*}{ Committee 4 Chair } & $1962-1985$ & Henri Jammet, France \\
\hline & 1985-1989 & H. John Dunster, UK \\
\hline & 1989-1993 & Roger H. Clarke, UK \\
\hline & 1993-1997 & Dan J. Beninson, Argentina \\
\hline & $1997-2003$ & Bert Winkler, South Africa \\
\hline & 2003-2009 & Annie Sugier, France \\
\hline & $2009-$ & Jacques Lochard, France \\
\hline Committee 5 Chair & $2005-$ & R. Jan Pentreath, UK \\
\hline
\end{tabular}

\subsubsection{5 and on: widening the scope beyond mankind}

(30) In 2003, the Commission decided to launch a fifth committee, devoted to environmental protection, at the start of the 2005-2009 term, and the name and mission statement of Committee 5 were formally decided in 2004.

(31) The names and mission statements of the present five committees are given in Table 1.1. The Chairs and Scientific Secretaries of the Commission are listed in 
Table 1.2, and the Chairs of the Sub-Committees and Committees are given in Table 1.3. The portrait annex at the end of this paper includes pictures of the Commission's Chairs and Scientific Secretaries, and some other key personalities.

\subsection{References}

Becquerel, H., 1896. Emission des radiations nouvelles par l'uranium metallique. C. R. Acad. Sci. Paris $122,1086$.

Churchill, W.S., 1898. The Story of the Malakind Field Force. Longman's Green \& Co., London.

Clarke, R.H., 2008. The International Commission on Radiological Protection $80^{\text {th }}$ Anniversary: the evolution of its policies through 80 years. In: Gallego, E., Pérez, M., Beatriz, G., et al. (Eds.), Strengthening Radiation Protection Worldwide, IRPA XII Congress. Available at: http://www.irpa12. org.ar/index.php.

Clarke, R.H., Valentin, J., 2005. A history of the International Commission on Radiological Protection. Health Physics 88, 407-422.

Clement, C., 2009. Personal communication.

Curie, M., 1898. Rayons emis par les composes de l'uranium et du thorium. C. R. Acad. Sci. Paris 126, 1101.

Drury, H.C., 1896. Dermatitis caused by Roentgen X-rays. Br. J. Med. 2, 1377.

Frieben, A., 1902. Demonstration eines Cancroid des rechten Handrückes, das sich nach langdauernder Einwirkung von Röntgenstrahlen entwickelt hat. Fortschr. Röntgenstr. 6, 106-111.

Fuchs, W., 1896. Simple recommendations on how to avoid radiation harm. Western Electrician 12.

Grubbé, E.H., 1933. Priority in the therapeutic use of X-rays. Radiology XXI, 156-162.

ICRP, 1951. International recommendations on radiological protection. Br. J. Radiol. 24, 46-53.

ICRP, 1955. Recommendations of the ICRP. Br. J. Radiol. (Suppl. 6) 100 pp.

ICRP, 1979a. Limits for intakes of radionuclides by workers. ICRP Publication 30, Part 1. Ann. ICRP 2(3/4).

ICRP, 1979b. Limits for intakes of radionuclides by workers. ICRP Publication 30, Supplement to Part 1. Ann. ICRP 3(1-4).

ICRP, 1980. Limits for intakes of radionuclides by workers. ICRP Publication 30, Part 2. Ann. ICRP 4(3/4).

ICRP, 1981. Limits for intakes of radionuclides by workers. ICRP Publication 30, Supplement to Part 2. Ann. ICRP 5(1-6).

ICRP, 1982a. Limits for intakes of radionuclides by workers. ICRP Publication 30, Part 3. Ann. ICRP $6(2 / 3)$.

ICRP, 1982b. Limits for intakes of radionuclides by workers. ICRP Publication 30, Supplement A to Part 3. Ann. ICRP 7(1-3).

ICRP, 1982c. Limits for intakes of radionuclides by workers. ICRP Publication 30, Supplement B to Part 3. Ann. ICRP 8(1-3).

ICRP, 1982d. Limits for intakes of radionuclides by workers. ICRP Publication 30, Index. Ann. ICRP $8(4)$.

ICRP, 1989. Limits for intakes of radionuclides by workers. ICRP Publication 30, Part 4 (Addendum). Ann. ICRP 19(4).

Leppin, O., 1896. Aus kleine Mitteilungen. Wirkung der Röntgenstrahlen auf die Haut. Dtsch. Med. Wschr. 28, 454.

Lindell, B., 1996a. The history of radiation protection. Rad. Prot. Dosim. 68, 83-95.

Lindell, B., 1996b. Pandoras Ask. Atlantis, Stockholm. (In Swedish; German translation 2004, Pandoras Büchse, Aschenbeck \& Isensee, Oldenburg).

Lindell, B., 1999. Damokles Svärd. Atlantis, Stockholm. (In Swedish; German translation 2006, Das Damoklesschwert. Aschenbeck \& Isensee, Oldenburg).

Lindell, B., 2003. Herkules Storverk. Atlantis, Stockholm. (In Swedish; German translation in preparation, Die Heldentaten des Herkules, Aschenbeck \& Isensee, Oldenburg). 
Molineus, W., Holthusen, H., Meyer, H., 1992. Ehrenbuch der Radiologen aller Nationen, third ed. Blackwell Wissenschaft, Berlin.

Mould, R.F., 1993. A Century of X Rays and Radioactivity in Medicine, second ed. CRC Press/Taylor \& Francis Group, London.

Sievert, R.M., 1957. The International Commission on Radiological Protection (ICRP). In: International Associations. Union of International Associations, Palais d'Egmont, Brussels, pp. 3-7.

Röntgen, W.C., 1895. Über eine neue Art von Strahlen. Sitzungsberichte d. Phys. Mediz. Ges. Würzburg 9, 132 .

Taylor, L.S., 1979. Organization for Radiation Protection: the Operations of the ICRP and NCRP 19281974. DoE/TIC 10124. US Department of Energy, Washington, DC. 


\section{HOW ICRP RECOMMENDATIONS EVOLVED}

(32) The early recommendations of IXRPC were concerned with avoiding threshold (deterministic) effects, initially in a qualitative manner.

\subsection{The initial stage: physical protection}

(33) The Committee issued its first recommendations (IXRPC, 1928), consisting of 41 paragraphs, in three and a half pages of recommendations on protection against $\mathrm{X}$ rays and radium.

(34) The 1928 Recommendations noted that 'The effects to be guarded against are injuries to superficial tissues, derangements of internal organs and changes in the blood'. As a remedy, a prolonged holiday and limitation of working hours were recommended. No form of dose limit was proposed, but Lindell (1998) estimated that occupational annual effective doses to medical staff at the time may have averaged around $1000 \mathrm{mSv}$. The main emphasis of the 1928 Recommendations was of a technical nature on shielding requirements. There was also some practical guidance on protection in Paragraphs 10 and 11:

'(10) An X-ray operator should on no account expose himself unnecessarily to a direct beam of X-rays.

(11) An operator should place himself as remote as practicable from the X-ray tube. It should not be possible for a well rested eye of normal acuity to detect in the dark appreciable fluorescence of a screen placed in the permanent position of the operator.'

\subsection{The first quantitative recommendations: tolerance dose}

(35) IXRPC met again at the 1931 ICR in Paris but did not issue any recommendations at the time. However, at the next meeting, in Zürich, the first set of recommendations including a 'dose limit' (a limit on exposure rate for X rays) were issued. It was still stated that the 'known effects to be guarded against [were] injuries to the superficial tissues [and] derangements of internal organs and changes in the blood' (IXRPC, 1934).

(36) Furthermore, implying the concept of a safe threshold below which no untoward effects were expected, the 1934 Recommendations claimed that 'the evidence at present available appears to suggest that under satisfactory working conditions a person in normal health can tolerate exposure to $X$ rays to an extent of about 0.2 international röntgens (r) per day. On the basis of continuous irradiation during a working day of seven hours, this figure corresponds to a dosage rate of $10^{-5} \mathrm{r}$ per second. The protective values given in these recommendations are generally in harmony with this figure under average conditions'. This would correspond to an annual effective dose of approximately $500 \mathrm{mSv}$, i.e. approximately 25 times the 
present annual limit for average occupational dose and approximately 10 times the present limit for occupational dose in any 1 year.

(37) In addition, the earlier (IXRPC, 1928) advice on working hours per day and per week, annual holiday, and freedom from 'other' hospital work were repeated in the 1934 Recommendations, and a requirement was added that 'X-ray, and particularly radium workers, should be systematically submitted, both on entry and subsequently at least twice a year, to expert medical, general and blood examinations. These examinations will determine the acceptance, refusal, limitation or termination of such occupation' (IXRPC, 1934).

(38) Interestingly, it was also stated that 'No similar tolerance dose is at present available in the case of radium gamma rays' (IXRPC, 1934). The general recommendations on shielding, electrical safety precautions (probably very important at the time), and working methods were extended. In addition, there was now advice on the safe storage of film, when non-flammable film was not available.

(39) The Commission met again at the next ICR meeting in Chicago in 1937. The amended recommendations issued at that time (IXRPC, 1938) were now for ' $\mathrm{X}$ rays and gamma rays', but did not differ from the 1934 Recommendations in any other respect than some extension of the practical guidance concerning shielding and electrical safety.

\subsubsection{Radiological protection at the dawn of the nuclear age}

(40) There were no further Commission recommendations before the Second World War. However, Sowby (1981) noted that the Commission's recommendations during the 1930s led to a great improvement in the standard of safety in radiological work. In particular, he stressed that the 'dose limits' introduced by ICRP served as the basis for the safety measures that were applied in the developing nuclear energy programmes. As a result, there were very few radiation injuries among the many thousands of workers involved in the early days of nuclear energy, despite the fact that large amounts of radioactive material were being handled.

\subsection{A broader range of hazards: maximum permissible dose}

(41) The first post-war meeting of the Commission, at the ICR in 1950, resulted in an 8-page report (ICRP, 1951). The Commission now recommended a maximum permissible dose of 0.5 röntgen in any 1 week in the case of whole-body exposure to $\mathrm{x}$ and gamma radiation (at the surface, corresponding to 0.3 röntgen in 'free air'), and 1.5 röntgen in any 1 week in the case of exposure of hands and forearms.

(42) In modern terminology, this corresponds approximately to an annual limit for occupational effective dose of $150 \mathrm{mSv}$ (although the meaning and concept of a dose limit was different at the time). The previous limit of 1 röntgen/week ( 0.2 röntgen/ day) was considered to be too 'close to the probable threshold for adverse effects'.

(43) The 1951 report of the Commission was quite comprehensive. There was a table of relative biological effectiveness (RBE) values and data on Standard Man. 
Maximum permissible body burdens were given for 11 nuclides, including $0.1 \mu \mathrm{g}$ for radium-226. It was recognised that in the case of uranium, it is the chemical toxicity and not radioactivity that is limiting. The 1950 Recommendations also provided an impressive list of the health effects that should be kept under review:

- superficial injuries;

- general effects on the body, particularly blood and blood-forming organs, e.g. production of anaemia and leukaemia;

- the induction of malignant tumours;

- other deleterious effects including cataract, [somewhat surprisingly] obesity, impaired fertility, and reduction of life span; and

- genetic effects.

(44) However, the casual reader might perceive the 1950 Recommendations to be somewhat inconsistent. On one hand, they mention 'permissible levels', 'maximum permissible exposure', and 'the probable threshold for adverse effects', all implying the existence of a safe threshold below which there would be no deleterious effects. On the other hand, they also mention the importance of carcinogenic and genetic effects (which, for the the latter effect at least, had been known for many years to operate at very low doses in experimental organisms), and it was 'strongly recommended that every effort be made to reduce exposures to all types of ionizing radiation to the lowest possible level'. The reduction of the 'dose limit' from approximately $500 \mathrm{mSv} / y e a r$ to approximately $150 \mathrm{mSv} /$ year was not necessarily only due to the perception of 'new' biomedical hazards. It may also have reflected the realisation that there could be individual variations in radiation sensitivity. In any case, the 1950 Recommendations reflect a wide range of different opinions within the Commission at the time.

(45) In summary, for the first 60 years after the discovery of ionising radiation, the purpose of radiological protection was that of avoiding deterministic effects from occupational exposures, and the principle of radiological protection was to keep individuals below the relevant thresholds. The ethical basis of radiological protection was hardly discussed in any formal way, and seems to have been essentially a case of Aristotelian virtue ethics, i.e. having an 'inner sense' of moral orientation. Low doses of radiation were deemed beneficial, largely because most uses of radiation were for medical purposes, and radioactive consumer products abounded.

\subsection{The need for change: public concern about radiation}

(46) The next meeting of ICRP was at the seventh ICR in Copenhagen in 1953. The meeting generated a much more substantial set of recommendations, later referred to as the 1954 Recommendations (although they were agreed in 1953 and printed in 1955), comprising 100 pages (ICRP, 1955). The 1954 Recommendations included both the Commission's own recommendations and reports from SubCommittees I-IV. The basic principle was re-iterated: 'Whilst the values proposed for maximum permissible doses are such as to involve a risk which is small compared to the other hazards of life, nevertheless, in view of the incomplete evidence 
on which the values are based, coupled with the knowledge that certain radiation effects are irreversible and cumulative, it is strongly recommended that every effort be made to reduce exposure to all types of ionizing radiation to the lowest possible level'. This seems to be the first time that the Commission tried to put radiation risks into some form of perspective by comparing them with risks due to other factors.

(47) In the mid-1950s, there was growing public concern about radiation risks. The 'atomic bombs' dropped over Hiroshima and Nagasaki in 1945; the extensive nuclear weapons testing after the Second World War, with considerably larger explosive yields and resulting radioactive contamination in the northern hemisphere; and incidents such as the contamination of the Japanese fishing boat, the Lucky Dragon, in 1954 (Lapp, 1958) all influenced public opinion significantly.

(48) This development was also of concern for ICRP. The Commission recognised the need to protect the general public in the case of increasing use of radioactive sources, and with nuclear energy expected to be an expanding industry. The major problem, based on experimental data, was believed to be hereditary harm, but the awareness of leukaemia among radiologists, and information about increased frequency of leukaemia among the survivors in Hiroshima and Nagasaki, also contributed to a decision to be cautious with regard to public exposures.

(49) Thus, a first recommendation on restrictions of exposures of members of the general public appeared in the Commission's part of the 1954 Recommendations: 'The Commission recommends that, in the case of the prolonged exposure of a large population, the maximum permissible levels should be reduced by a factor of ten below those accepted for occupational exposures'. This is somewhat unspecific in the sense that 'large' populations was not defined, but it heralded the factor of 10 reduction that would, for many years, apply to the difference between occupational and public exposures.

(50) In this context, it is perhaps worth re-iterating that the Commission has never argued that there would be any reason (such as knowing the hazard, and/or receiving a high salary including some form of risk premium) to permit 'more' radiation in occupational contexts. Instead, the Commission's view has been and is that 'less' radiation should be permitted for the general public. Initially, this position was taken perhaps primarily in view of possible genetic effects, and later on the grounds that the general public includes more sensitive persons such as children and those suffering from diseases.

(51) In the report of Sub-Committee I in the 1954 Recommendations, it was stated that 'since no radiation level higher than the natural background can be regarded as absolutely "safe", the problem is to choose a practical level that, in the light of present knowledge, involves a negligible risk'. However, the Commission had not rejected the possibility of a threshold for stochastic effects.

(52) The Commission realised that it would no longer be sufficient to express all exposure restrictions in röntgen units. The 1954 Recommendations (ICRP, 1955) contained a glossary defining absorbed dose and the corresponding unit, rad (=0.01 Gy in modern terms), as described by ICRU. Sub-Committee I also introduced a new RBE-weighted unit, the rem $(=0.01 \mathrm{~Sv}$ in modern terms). 
(53) The concept of critical organ was now introduced, and the recommended dose limit was related to the organs that were said to be critical in the case of whole-body exposure, i.e. the gonads and the blood-forming organs. The limit, expressed in the new unit, was given as $0.3 \mathrm{rem} / \mathrm{week}$, i.e. still corresponding to an annual occupational effective dose of the order of $150 \mathrm{mSv}$.

(54) The report of Sub-Committee II included tables on maximum permissible concentrations (MPC) in air and water for occupational exposure to some 90 radionuclides. These MPC values were all based on a weekly dose of 0.3 rem to the organ that was critical in each case. Concerning public exposures, it stated that 'Following accepted practice in the industrial and public health field, and keeping in mind the uncertainties involved and the fact that in the future some of the values given in this report may be lowered, it is recommended, in the case of prolonged exposure of a large population, to reduce by a factor of 10 the permissible level for radioactive isotopes accepted for occupational exposures. The values given in this report are for occupational exposure and are understood to be additional to natural background'.

(55) Furthermore, the Sub-Committee II report claimed that 'Exposure for a lifetime at the maximum permissible values recommended in this report is not expected, in the light of present knowledge, to cause appreciable body damage'. Since SubCommittee I had specified that " appreciable bodily injury" means any bodily injury or effect that a person would regard as being objectionable and/or competent medical authorities would regard as being deleterious to the health and well-being of the individual', this seems to imply the existence of a 'safe threshold'. Nevertheless, SubCommittee II also stated that 'The application of the safety factor of 10 will reduce the risks of genetic damage that are a consequence of a large average exposure to the population'; thus the genetic risk, for which there was little reason to presume any threshold, was the primary concern.

(56) The Sub-Committee III report included an interesting proposal: 'In view of the continually increasing medical and technical use of ionizing radiation, it is desirable to accumulate information regarding the doses received both by individuals and by the population as a whole. As far as the individual is concerned, the information could be obtained by the introduction of a certificate in which are recorded details of all radiation exposure (medical and occupational) received through life. Probably it is impracticable to introduce such a certificate at present, but it is recommended that all radiologists and dentists keep records of the doses given'. The concept of an individual certificate for all forms of exposure never caught on, but of course nowadays significant occupational exposures are registered and stored electronically.

\subsubsection{The 1956/57 amendment: controlled areas; pregnant women}

(57) At its 1956 meeting in Geneva, the Commission concluded that the 1954 Recommendations needed a major and essential revision, implying substantial limitations of the MPC levels recommended earlier. However, it became obvious that a complete revision could not be completed before the summer of 1958. In order to promulgate the major points, the Commission released a 3-page amendment (ICRP, 1957) with several interesting conclusions. Thus, 'A controlled area is one in which 
the occupational exposure of personnel to radiation or radioactive material is under the supervision of a radiation safety officer', and 'For any person in any place outside of controlled areas, the maximum permissible levels of exposure are $10 \%$ of the occupational exposure levels'. In other words, personnel working outside a controlled area were to be given the same level of protection as members of the public.

(58) For the entire population, in view of the genetic dose, 'it is prudent to limit the dose of radiation received by gametes from all sources additional to the natural background to an amount of the order of the natural background in presently inhabited regions of the earth'.

(59) Furthermore, 'Since it is known from animal experiments that the embryo is very radiosensitive, special care should be exercised to make sure that pregnant women are not occupationally exposed under conditions in which, through some accident or otherwise, they may be exposed to large doses of penetrating radiation. When the exposure cannot exceed the basic permissible weekly dose, however, no special provisions need be made'. This was the Commission's first specific advice for pregnant women, and at the same time, the first observation that a steady dose rate is essential for the protection of the embryo and fetus.

\subsection{The beginnings of the modern era: ICRP Publication 1}

(60) In 1957, there was pressure on ICRP from both WHO and UNSCEAR to reveal all of the decisions from its 1956 meeting in Geneva. The final document, the Commission's 1958 Recommendations (ICRP, 1959a [adopted in September 1958]) was the first ICRP report published by Pergamon Press. Although it had no number, the next report (ICRP, 1959b) had 'Publication 2' printed on the cover, and therefore the 1958 Recommendations are usually referred to as 'Publication 1'.

(61) The 1958 Recommendations, 22 pages comprising 87 paragraphs, began with a 'Prefatory review' and was the first time that the basis of the Commission's policy was presented and discussed. Both the 1954 and the 1958 Recommendations include a paragraph headlined 'Policy', but this just refers to the administrative policy of dealing with the basic principles of radiological protection and leaving detailed technical regulations to national bodies. The protection policy review in the 1958 Recommendations is printed in the Prefatory review.

(62) The weekly dose limit of 0.3 rem was replaced by a limit of the accumulated dose equivalent, $D=5(N-18)$ where $D$ is dose in rems and $N$ is age in years, corresponding to an average annual occupational effective dose of $5 \mathrm{rem}(50 \mathrm{mSv})$. For individual members of the public, the dose limit was set at $0.5 \mathrm{rem}(5 \mathrm{mSv}) / \mathrm{year}$ and, in addition, a genetic dose limit of $5 \mathrm{rem} /$ generation was suggested together with a long and detailed 'illustrative apportionment'.

(63) At that time, the Commission's basic policy was mainly determined by Committee I. The 1958 Recommendations were soon supplemented with Publication 2 (ICRP, 1959b), a major document on internal emitters and with comprehensive tables on maximum permissible body burdens and MPC values, and Publication 3 (ICRP, 1960), on protection against $X$ rays and $\beta$ and $\gamma$ rays from sealed sources. 
Together, Publications 1-3 definitely established ICRP as the leading international radiation protection authority.

(64) Publication 1 was soon subject to a number of amendments, and the Commission therefore issued a revised version, Publication 6 (ICRP, 1964) in which these amendments were incorporated. This also included new MPC values for strontium-90 and some isotopes of transuranic elements.

\subsection{Taking stochastic effects into account: the linear, no-threshold model}

(65) The significance of stochastic effects began to influence the Commission's policy more and more. It was soon time for more substantial revisions, and a new set of recommendations was published as Publication 9 (ICRP, 1966b). During the drafting of Publication 9, its editorial group had been concerned about the many different opinions regarding the risk of stochastic effects. The Commission therefore asked a working group 'to consider the extent to which the magnitude of somatic and genetic risks associated with exposure to radiation can be evaluated'. Their report, Publication 8 (ICRP, 1966a) was an important document because, for the first time in ICRP publications, it summarised the current knowledge about radiation risks, both somatic and genetic. The probability of leukaemia after an absorbed dose of $1 \mathrm{rad}$ of gamma radiation (i.e. $10 \mathrm{mGy}$ ) was estimated at 20 cases per million exposed. However, it was then assumed that the probability of all other types of cancer together was about the same as the probability of leukaemia; an assumption that was later shown to have been an underestimate.

\subsubsection{Acceptable risks}

(66) Prolonged debate followed regarding how to deal with the acceptability of the risks. In Publication 1, the 1954 words 'lowest possible' were succeeded by 'as low as practicable'. In Publication 9, the usual cautious warning (in Paragraph 52) read: 'As any exposure may involve some degree of risk, the Commission recommends that any unnecessary exposure be avoided and that all doses be kept as low as is readily achievable, economic and social consequences being taken into account'.

(67) Other considerations, such as ethical issues, were not excluded by this wording, but the Commission considered them to be included in the adjective 'social'. No guidance existed regarding how this recommendation should be applied. However, the Commission was increasingly doubtful of the existence of a threshold dose for the induction of cancer. Paragraph 7 stated that 'the Commission sees no practical alternative, for the purposes of radiological protection, to assuming a linear relationship between dose and effect, and that doses act cumulatively. The Commission is aware that the assumptions of no threshold and of complete additivity of all doses may be incorrect, but is satisfied that they are unlikely to lead to the underestimation of risks'.

(68) Now there were stochastic effects, where the probability of the effect, not the severity, is proportional to the size of the dose, the assumption of a threshold was rejected. The problem had become one of limiting the probability of harm. Much 
of the subsequent development related to the estimation of that probability of harm, and the decision on what level of implied risk is acceptable or, more importantly, unacceptable. From the mid-1960s, the main field of interest was the expanding nuclear industry. The protection philosophy was definitely shaped by the assumption of a linear dose-response relationship without any threshold dose.

(69) Publication 9 substantially renewed the radiation protection philosophy by moving from deterministic to stochastic effects. It made a distinction between "normal operations' and accidents where the exposure 'can be limited in amount only, if at all, by remedial action'. The age-prorated formula was abandoned and the MPC for the gonads and the blood-forming organs was now expressed as an annual dose of 5 rem (i.e. $50 \mathrm{mSv}$ ). The term 'dose limit' was introduced for the annual limit of 0.5 rem recommended for public exposures.

(70) Paragraph 52 in Publication 9, recommending that 'all doses be kept as low as is readily achievable, economic and social consequences being taken into account', called for further guidance. The Commission therefore appointed a task group, which reported in Publication 22 (ICRP, 1973) that the optimum level of protection might be found by means of differential cost-benefit analysis and that the principle described in Paragraph 52 of Publication 9 was the principle of optimisation of protection.

(71) At that time, ICRP had a new editorial group working on a revision of Publication 9 and proposed some rather radical changes. The concept of 'critical organ' was abandoned. It was felt that there was sufficient knowledge of the cancer risk for a number of organs to permit the calculation of a weighted whole-body dose. A quantity based on such weighting had already been suggested by Jacobi (1975), but in the new recommendations, the Commission only introduced the weighting procedure without presenting the result as a new quantity. This was first made in a statement (ICRP, 1978), when the name 'effective dose equivalent' was introduced, following Wolfgang Jacobi's proposal.

\subsection{A system of dose limitation}

(72) Publication 26 (ICRP, 1977), the Commission's 1977 Recommendations, first quantified the risks of stochastic effects of radiation and proposed a system of dose limitation. The 1977 Recommendations stated in Paragraph 6 that 'Radiation protection is concerned with the protection of individuals, their progeny and mankind as a whole, while still allowing necessary activities from which radiation exposure might result'. The 1977 Recommendations then went on to say in Paragraph 14 that 'Although the principal objective of radiation protection is the achievement and maintenance of appropriately safe conditions for activities involving human exposure, the level of safety required for the protection of all human individuals is thought likely to protect other species, although not necessarily individual members of those species. The Commission therefore believes that if man is adequately protected then other living things are also likely to be sufficiently protected'. 
(73) This was the first occasion on which the Commission addressed the effects of radiation on species other than mankind, although clearly it was not pursued. Much of the work of ICRP was concentrated upon the development of human biokinetic data, and the assessment of doses for workers and the public from the ranges of radionuclides likely to be encountered. This included the development of Reference Man to develop standardised dose-intake data.

(74) Publication 26 set out the new system of dose limitation and introduced the three principles of protection in Paragraph 12:

(a) no practice shall be adopted unless its introduction produces a positive net benefit;

(b) all exposures shall be kept as low as reasonably achievable, economic and social factors being taken into account; and

(c) the doses to individuals shall not exceed the limits recommended for the appropriate circumstances by the Commission'.

These principles have since become known as justification, optimisation (as low as reasonably achievable), and the application of dose limits.

(75) The principle of optimisation was to generate much important work for ICRP, as well as other international and national bodies. The principle was introduced because of the need to find some way of balancing costs and benefits of the introduction of a source involving ionising radiation or radionuclides. This process was not necessarily sufficient to protect individuals, so it was complemented by the dose limits. As a result of introducing this requirement, doses to non-human species were certainly reduced to some extent in the majority of situations.

(76) The 1977 Recommendations were very concerned with the bases for deciding what is reasonably achievable in dose reduction. The principle of justification aims to do more good than harm, and that of optimisation aims to maximise the margin of good over harm for society as a whole. They therefore satisfy the utilitarian principle of ethics, also called 'consequence ethics', proposed primarily by Jeremy Bentham and John Stuart Mill (Mill, 2002). Utilitarians judge actions by their overall consequences, usually by comparing, in monetary terms, the relevant benefits (e.g. statistical estimates of lives saved) obtained by a particular protective measure with the net cost of introducing that measure.

(77) On the other hand, the principle of applying dose limits aims to protect the rights of the individual not to be exposed to an excessive level of harm, even if this could cause great problems for society at large. This principle therefore satisfies the deontological principle of ethics, also called 'duty ethics', proposed primarily by Immanuel Kant (Broad, 1978). Proponents of this principle emphasise the strictness of moral limits.

(78) Paragraph 72 of Publication 26 suggests that the decision on what is 'as low as reasonably achievable' depends on the answer to the question 'whether or not the activity [under scrutiny] is being performed at a sufficiently low level of collective dose equivalent (and usually, therefore, of detriment) so that any further reduction in dose would not justify the incremental cost required to accomplish it'. 
(79) Paragraph 75 of Publication 26 recommended the use of differential costbenefit analysis where the independent variable is the collective dose, and recommended that a monetary value should be assigned to a unit of collective dose. This classical use of cost-benefit analysis addresses the question: 'How much does it cost and how many lives are saved?' However, this approach does not allow for the protection of the individual from the source, so ICRP retained the concept of a dose limit to protect the individual from all sources under control.

(80) The concept of the collective dose was originally introduced for two reasons, one of which was to facilitate cost-benefit analysis. The second reason for using collective dose was to restrict the uncontrolled build-up of exposure to long-lived radionuclides in the environment. This was because, at the time, a global expansion of nuclear power reactors and reprocessing facilities was foreseen, and there were fears that global doses could again reach the levels seen from atmospheric testing of nuclear weapons. Restricting collective dose per unit of practice can effectively set a maximum future annual effective per caput dose from all sources from that practice.

(81) In 1977, the establishment of the dose limits was of secondary concern to the establishment of cost-benefit analysis and use of collective dose. This can be seen in the wording used in Publication 26 in setting its dose limit for members of the public: 'The assumption of a total risk of the order of $10^{-2} \mathrm{~Sv}^{-1}$ would imply restriction of the lifetime dose to the individual member of the public to $1 \mathrm{mSv} / \mathrm{year}$. The Commission's recommended limit of $5 \mathrm{mSv}$ in a year, as applied to critical groups, has been found to give this degree of safety and the Commission recommends its continued use'.

(82) In a similar manner, the dose limit for workers was argued on a comparison of average doses, and therefore risk, in the workforce, with average risks in industries that would be recognised as being 'safe', and not on maximum risks to be accepted.

\subsection{Acceptability vs risk: tolerable detriment}

(83) During the 1980s, there were re-evaluations of the risk estimates derived from the survivors of the atomic bombing at Hiroshima and Nagasaki, partly due to revisions in the dosimetry. The risks of exposure were claimed to be higher than those used by ICRP, and pressures began to appear for a reduction in dose limits. This represented the start, as now seen with hindsight, of the rise of concern regarding the individual. ICRP's response was initially to emphasise the principle of optimisation and to claim that the use of collective dose and cost-benefit analysis always ensured that individual doses were sufficiently low.

(84) However, by 1989, the Commission had itself revised upwards its estimates of the risks of carcinogenesis from exposure to ionising radiation. The following year, it adopted its 1990 Recommendations (ICRP, 1991) for a 'system of radiological protection'. The principles of protection recommended by the Commission were still based on the general principles given in Publication 26, but with important additions:

(a) No practice involving exposures to radiation should be adopted unless it produces sufficient benefit to the exposed individuals or to society to offset the radiation detriment it causes. (The justification of a practice); 
(b) In relation to any particular source within a practice, the magnitude of individual doses, the number of people exposed, and the likelihood of incurring exposures where these are not certain to be received should all be kept as low as reasonably achievable, economic and social factors being taken into account. This procedure should be constrained by restrictions on the doses to individuals (dose constraints), or on the risks to individuals in the case of potential exposures (risk constraints) so as to limit the inequity likely to result from the inherent economic and social judgements. (The optimisation of protection);

(c) The exposure of individuals resulting from the combination of all the relevant practices should be subject to dose limits, or to some control of risk in the case of potential exposures. These are aimed at ensuring that no individual is exposed to radiation risks that are judged to be unacceptable from these practices in any normal circumstances. (Individual dose and risk limits)'.

(85) The most significant change was in the principle of optimisation and the introduction of the concept of a constraint. Optimisation is a source-related process, while limits apply to the individual to ensure protection from all sources under control. The aim of dose limitation is to ensure that no individual is exposed to an unacceptable level of risk from all the regulated sources. The constraint is an individualrelated criterion, applied to a single source in order to ensure that the most exposed individuals are not subjected to undue risk from that source. Classical cost-benefit analysis is unable to take this into account, so the Commission established an added restriction on the optimisation process, the maximum individual dose (or risk= probability of exposure) from the source, i.e., the constraint.

(86) In Publication 77 (ICRP, 1998), the Commission observed that 'The optimisation of protection has the broad interpretation of doing all that is reasonable to reduce doses. In some ways it is unfortunate that the shorthand label "optimisation of protection" lost the adjective "reasonable" in the phrase "as low as reasonably achievable". Furthermore, the perception of optimisation of protection has become too closely linked to differential cost-benefit analysis'. Furthermore, it was stated that 'The unlimited aggregation of collective dose over time and space into a single value is unhelpful because it deprives the decision maker of much necessary information. The levels of individual dose and the time distribution of collective dose may be significant factors in making decisions'.

(87) In other words, this report weakened the link to cost-benefit analysis and collective dose. Thus, concern for the protection of the individual was being strengthened. This was a reflection of changing societal values, with more concern about individual welfare.

\subsection{Emphasising individual rights, widening the scope to all species}

(88) Since Publication 60, a series of publications has provided additional guidance for the control of exposures from radiation sources. When the 1990 Recommendations are included, these reports specify some 30 different numerical values for 
restrictions on individual dose for differing circumstances. Furthermore, these numerical values are justified in many different ways (ICRP, 2006). In addition, the Commission began to develop policy guidance for protection of non-human species in Publication 91 (ICRP, 2003).

(89) The Commission was elaborating its policy but it was clear that there were some misunderstandings of its concepts, in particular, the difference between source-related and individual-related protection. The dose limit as defined in the 1990 Recommendations only applies in defined conditions, but many people regarded a limit as being absolute. The use of higher doses for emergencies and for radon in homes was seriously confusing. The Commission had tried to clarify this by distinguishing between 'practices' that added doses and 'interventions' that subtracted doses, but the distinction was not clearly understood.

(90) Other factors that caused concern included the excessive formality of the use of differential cost-benefit analysis and the rigid interpretation of collective dose by some practitioners. This led to the initiation of a wide-ranging open review of the basis for protection philosophy (Clarke, 1999).

(91) The Commission prepared Publication 103, its 2007 Recommendations (ICRP, 2007), after two phases of international public consultation on drafts, one in 2004 and one in 2006, as well as presentations to IRPA and other international bodies as the drafts were developed. This process follows nearly a decade of a policy of transparency and involvement of those with a serious interest in protection, which the Commission expects to lead to a clear understanding and wide acceptance of its 2007 Recommendations.

(92) There is, therefore, more continuity than change in the 2007 Recommendations. Some recommendations remain because they work and are clear, others have been updated because understanding has evolved, some items have been added because there has been a void, and some concepts are better explained because more guidance is needed. The 2007 Recommendations re-iterate and strengthen the importance of optimisation in radiological protection, and extend the successful experience in the implementation of this requirement for practices (now included in planned exposure situations) to other situations, i.e. emergency and existing exposure situations. They also include a commitment to environmental protection.

\subsection{References}

Broad, C.D., 1978. Kant: an Introduction. Cambridge University Press, Cambridge.

Clarke, R.H., 1999. Control of low-level radiation exposure: Time for a change? J. Radiol. Prot. 19, 107115.

ICRP, 1951. International recommendations on radiological protection. Revised by the International Commission on Radiological Protection and the $6^{\text {th }}$ International Congress of Radiology, London, 1950. Br. J. Radiol. 24, 46-53.

ICRP, 1955. Recommendations of the International Commission on Radiological Protection. Br. J. Radiol. (Suppl. 6) 100 pp.

ICRP, 1957. Reports on amendments during 1956 to the Recommendations of the International Commission on Radiological Protection (ICRP). Acta Radiol. 48, 493-495. 
ICRP, 1959a. Recommendations of the International Commission on Radiological Protection. ICRP Publication 1. Pergamon Press, Oxford.

ICRP, 1959b. Recommendations of the International Commission on Radiological Protection. ICRP Publication 2: Report of Committee II on Permissible Dose for Internal Radiation. Pergamon Press, Oxford.

ICRP, 1960. Recommendations of the International Commission on Radiological Protection. ICRP Publication 3: Report of Committee III on Protection Against X-Rays up to Energies of $3 \mathrm{MeV}$ and Beta- and Gamma-rays from Sealed Sources. Pergamon Press, Oxford.

ICRP, 1964. Recommendations of the International Commission on Radiological Protection. ICRP Publication 6. Pergamon Press, Oxford.

ICRP, 1966a. The Evaluation of Risks from Radiation; a Report of Committee 1 of ICRP. ICRP Publication 8. Pergamon Press, Oxford.

ICRP, 1966b. Recommendations of the International Commission on Radiological Protection. ICRP Publication 9. Pergamon Press, Oxford.

ICRP, 1973. Implications of Commission Recommendations that Doses be Kept as Low as Readily Achievable. ICRP Publication 22. Pergamon Press, Oxford.

ICRP, 1977. Recommendations of the International Commission on Radiological Protection. ICRP Publication 26. Ann. ICRP 1(3).

ICRP, 1978. Statement from the 1978 Stockholm Meeting of the ICRP. ICRP Publication 28. Ann. ICRP $2(1)$.

ICRP, 1991. 1990 Recommendations of the International Commission on Radiological Protection. ICRP Publication 60. Ann. ICRP 21(1-3).

ICRP, 1998. Radiological protection policy for the disposal of radioactive waste. ICRP Publication 77. Ann. ICRP 27(Suppl.).

ICRP, 2003. A framework for assessing the impact of ionising radiation on non-human species. ICRP Publication 91. Ann. ICRP 33(3).

ICRP, 2006. Analysis of the criteria used by ICRP to justify the setting of numerical values. ICRP Supporting Guidance 5. Ann. ICRP 36(4).

ICRP, 2007. The 2007 Recommendations of the International Commission on Radiological Protection. ICRP Publication 103. Ann. ICRP 37(2-4).

IXRPC, 1928. X-ray and Radium Protection. Recommendations of the $2^{\text {nd }}$ International Congress of Radiology, 1928. Br. J. Radiol. 12, 359-363.

IXRPC, 1934. International Recommendations for X-ray and Radium Protection. Revised by the International X-ray and Radium Protection Commission and adopted by the $4^{\text {th }}$ International Congress of Radiology, Zürich, July 1934. Br. J. Radiol. 7, 1-5.

IXRPC, 1938. International Recommendations for X-ray and Radium Protection. Revised by the International X-ray and Radium Protection Commission at the $5^{\text {th }}$ International Congress of Radiology, Chicago, September 1937. Br. Inst. Radiol. (leaflet) 1-6.

Jacobi, W., 1975. The concept of the effective dose - a proposal for the combination of organ doses. Rad. Environm. Biophys. 12, 101-109.

Lapp, R.E., 1958. The Voyage of the Lucky Dragon. Harper \& Bros., New York.

Lindell, B., 1998. Personal communication.

Mill, J.S., 2002. Utilitarianism and On Liberty. Including 'Essay on Bentham' and Selections from the Writings of Jeremy Bentham and John Austin. Warnock, M. (Ed.), second ed. Blackwell Publishing, Oxford.

Sowby, F.D., 1981. Radiation protection and the International Commission on Radiological Protection (ICRP). Radiat. Prot. Dosim. 1, 237-240. 



\section{ANALYSIS OF TRENDS AND CONCLUSION}

\subsection{The formal status of ICRP}

(93) ICRP is an independent, international, non-governmental organisation. It remains one of three commissions of the International Society for Radiology, the others being ICRU and the International Commission for Radiological Education and Information (ICRE), and the parent body approves the rules by which the three commissions operate. Various international (but not national) organisations are invited to send observers to ICRP meetings, and ICRP has a corresponding observer status in such organisations.

(94) The 1934 meeting of IXRPC and the membership discussions at that time was the first, but certainly not the last, time that the Commission's independence and scientific integrity were jeopardised by demands from special interest groups and other outsiders with vested interests. It still happens from time to time that the Commission is subjected to demands or covert criticisms aimed at gaining outside control of its membership and/or its policies. The Commission is very wary of such attempts and maintains as its strict policy that, as for ICRU and ICRE, members are elected by the Commission itself. Outside nominations are accepted as a means to achieve the widest possible range of expertise, but the actual elections are made by the Commission alone, and solely on the grounds of scientific merit, not as representatives of any country, organisation, or other entity.

\subsubsection{Science, policy, legislation, and the role of ICRP}

(95) Fig. 3.1 shows the relationship between different organisations with an interest in radiological protection. ICRP uses the summaries of basic scientific studies provided by UNSCEAR (e.g. UNSCEAR, 2006) as a primary source of information; it also takes account of scientific developments reported by major national organisations (e.g. the Biologic Effects of Ionizing Radiation reports of the US National Academies). Such scientific studies and summaries answer the questions 'How much radiation is there?' and 'How dangerous is it?'.

(96) Using that information as an input, the Commission proposes protection policies aimed at both legislators and regulators, operators and licensees, and, ultimately, members of the public (e.g. ICRP, 2007). Initially, and well through the 1960 s, some of the advice given was of a very practical nature. More recently, with an increased availability of expertise in health physics, radiobiology, and radiological protection, ICRP recommendations focus primarily on the strategy of protection the 'whether' and 'why' rather than the 'how'.

(97) The transparency of ICRP operations and the interaction with society have increased significantly in recent years. For instance, since 2002, all draft ICRP reports are subjected to public consultation using the Internet. Professional bodies, such as IRPA and, of course, ISR, provide important input to the Commission in this process. 


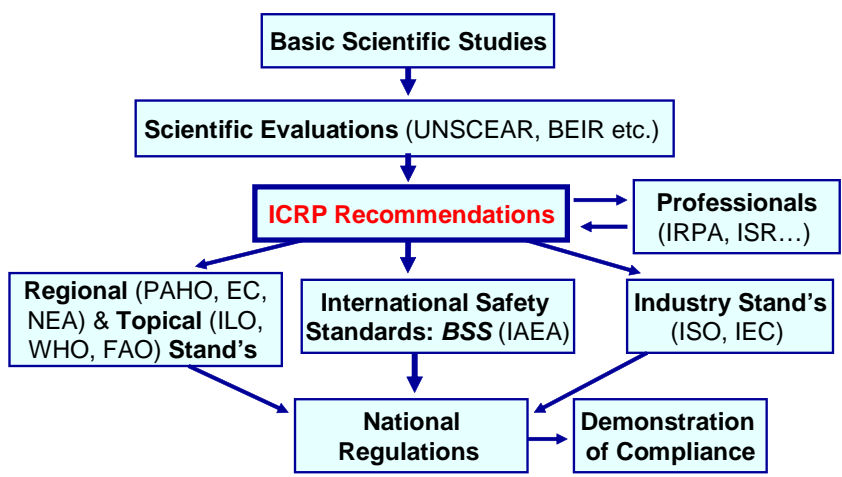

Fig. 3.1. The basis for and use of ICRP recommendations on radiological protection policy.

(98) The international organisations of the United Nations system utilise the recommendations of ICRP when producing their Basic Safety Standards for radiation protection (IAEA, 1996). The recommendations and advice of ICRP also influence documents on specific issues produced by specialised United Nations agencies, such as ILO, WHO, FAO, and IAEA. The Pan-American Health Organization, the European Commission, and the Nuclear Energy Agency of the Organisation for Economic Co-operation and Development (OECD) can be regarded as regional organisations (with OECD an economic region rather than a geographic region); they all take account of ICRP advice when producing documents pertaining to radiological protection. The International Electrotechnical Commission and ISO take ICRP advice into account when producing standards.

(99) Thus, neither the idea of a hierarchy of national and international committees and commissions (cf. Section 1.4.2) nor Rolf Sievert's vision of ICRP as a central intergovernmental international agency was implemented. However, with hindsight, the current system seems quite adequate. With UNSCEAR providing scientific summaries of levels and effects of radiation, ICRP providing policy recommendations, and the various intergovernmental agencies with an interest in radiological protection proposing regulations, purely scientific factors, political factors, and stakeholder demands are all given their due consideration but at separate and clearly identifiable stages.

\subsection{Different aspects of the development of ICRP recommendations}

(100) Table 3.1 summarises a number of different parameters characterising the Commission's recommendations over the years.

\subsubsection{Exposure conditions considered}

(101) Before the Second World War, the Commission's recommendations were entirely devoted to occupational exposures in medicine. Medical applications 
Table 3.1. The historical development of ICRP recommendations.

\begin{tabular}{|c|c|c|c|}
\hline Factor analysed & Early recommendations & $\begin{array}{l}\text { Intermediate } \\
\text { recommendations }\end{array}$ & $\begin{array}{l}\text { Present } \\
\text { recommendations }\end{array}$ \\
\hline $\begin{array}{l}\text { Circumstances of } \\
\text { exposure considered }\end{array}$ & $\begin{array}{l}\text { Occupational exposure } \\
\text { in medicine }\end{array}$ & $\begin{array}{l}\text { All occupational } \\
\text { exposure, then all } \\
\text { exposure of mankind }\end{array}$ & $\begin{array}{l}\text { All exposure of all } \\
\text { species }\end{array}$ \\
\hline $\begin{array}{l}\text { Who/what is being } \\
\text { protected }\end{array}$ & Protection of man alone & $\begin{array}{l}\text { Environment assumed } \\
\text { protected because man is } \\
\text { protected }\end{array}$ & $\begin{array}{l}\text { Demonstration that } \\
\text { environment is protected }\end{array}$ \\
\hline $\begin{array}{l}\text { Known effects of } \\
\text { radiation exposure, } \\
\text { aims of radiological } \\
\text { protection }\end{array}$ & $\begin{array}{l}\text { Prevent deterministic } \\
\text { effects... }\end{array}$ & $\begin{array}{l}\ldots \text { and avoid stochastic } \\
\text { effects... }\end{array}$ & $\begin{array}{l}\ldots \text { and recognise the } \\
\text { possibility of non- } \\
\text { targeted effects }\end{array}$ \\
\hline $\begin{array}{l}\text { The ethical basis of } \\
\text { protection }\end{array}$ & $\begin{array}{l}\text { 'Respect for life' virtue } \\
\text { ethics }\end{array}$ & $\begin{array}{l}\text { Focus on utilitarian } \\
\text { ethics }\end{array}$ & $\begin{array}{l}\text { Increasing emphasis on } \\
\text { deontological ethics }\end{array}$ \\
\hline Protection methods & $\begin{array}{l}\text { Advice on practical } \\
\text { protection methods }\end{array}$ & $\begin{array}{l}\text { Application of dose } \\
\text { limits, then application } \\
\text { of optimisation }\end{array}$ & $\begin{array}{l}\text { Optimisation of } \\
\text { protection under dose } \\
\text { and risk constraints }\end{array}$ \\
\hline
\end{tabular}

dominated the use of radiation entirely. Doses to staff were, by today's standards, extremely high, and it was assumed that there was a safe threshold below which radiation would cause no harm. The advent of accelerators and, soon thereafter, of nuclear reactors meant that suddenly there was an abundance of different radionuclides which were used for all sorts of purposes in many different professions. Consequently, the recommendations of the early 1950s were aimed at all occupational uses of radiation. The dawning realisation, during the mid- and late 1950s, that ionising radiation is a genotoxic agent meant that a linear, non-threshold model of radiation - dose response - had to be adopted. As a result, radiological protection had to take account of public exposures and medical exposures of patients, as well as occupational exposures.

\subsubsection{Scope of protection}

(102) Initially, radiological protection only aimed to protect human beings. Publication 26 (ICRP, 1977) suggested that 'the level of safety required for the protection of all human individuals is thought likely to be adequate to protect other species, although not necessarily individual members of those species. The Commission therefore believes that if man is adequately protected then other living things are also likely to be sufficiently protected'. Thus, protection of other species was seen as a perk rather than an actual aim. Publication 60 (ICRP, 1991) re-iterated much the same position, and also clarified that any protection of non-human species was regarded as important only insofar as it may have affected mankind through environmental transfer: 'The Commission believes that the standard of environmental control needed to protect man to the degree currently thought desirable will ensure that other species are not put at risk. Occasionally, individual members of nonhuman species might be harmed, but not to the extent of endangering whole species 
or creating imbalance between species. At the present time, the Commission concerns itself with mankind's environment only with regard to the transfer of radionuclides through the environment, since this directly affects the radiological protection of man'.

(103) The Commission started to think about protection of non-human species in their own right in Publication 91 (ICRP, 2003) and the 2007 Recommendations (ICRP, 2007). The reason behind this change is not any serious concern about existing radiation hazards. It is rather a matter of filling a conceptual gap by providing scientific evidence, rather than just assumptions, to show that other species are adequately protected.

\subsubsection{Known effects of ionising radiation and corresponding protection aims}

(104) Anecdotal evidence of radiation-induced cancer was available within less than 10 years of the discovery of ionising radiation, and the mutagenic effect of such radiation had been studied in some detail in experimental organisms before 1930 . Nevertheless, before the Second World War, only deterministic effects of radiation were considered in radiological protection, and the aim was to prevent such effects.

(105) During the 1950s, attention to the potential for radiation-induced stochastic effects increased, and in Publication 9 (ICRP, 1966), this was taken into account in the description of the aims of radiological protection: 'The objectives of radiation protection are to prevent acute radiation effects, and to limit the risks of late effects to an acceptable level'.

(106) More recently, the discovery of non-targeted effects, which cannot easily be classified as either deterministic or stochastic, has complicated the picture. However, the 2007 Recommendations of ICRP state that 'induced genomic instability and bystander signalling ... may influence radiation cancer risk ..., but that current uncertainties on the mechanisms and tumorigenic consequences of the above processes are too great for the development of practical judgements'. Furthermore, 'The Commission also notes that since the estimation of nominal cancer risk coefficients is based upon direct human epidemiological data, any contribution from these biological mechanisms would be included in that estimate'.

\subsubsection{The ethical basis of radiological protection}

(107) Before the Second World War, the ethical basis of radiological protection was not formally discussed. Its sole aim was to prevent deterministic harm to individual human beings, and this can be seen simply as an example of 'virtue ethics'.

(108) With increasing weight being given to optimisation in the 1960s and 1970s, the recommendations of ICRP were largely based on utilitarian consequence ethics, emphasising what is best for society. The recommendations from ICRP that have been made in the last 10 years have emphasised controls on the maximum dose or risk to the individual. There has been a corresponding reduction in the emphasis on collective dose and cost-benefit analysis. Overall, this reflects a shift of emphasis of the ethical position, paying less attention to utilitarian values. Instead, the 
Commission has now increased its emphasis on deontological duty ethics, emphasising what is best for the individual.

(109) Inevitably, radiological protection (and indeed any form of regulation or protection against some noxious agent) will require a balancing between these two ethical principles. No practical protection work can be based on an absolute application of one principle alone; however, one can give more emphasis to one of the principles without entirely discarding the other (Hansson, 2007). This is the development seen from Publication 26 to Publication 103.

\subsubsection{Protection methods}

(110) The Commission's early recommendations paid considerable attention to the practical aspects of shielding, working methods, and so forth. When numerical advice was introduced, it was in terms of dose limits (or, at least, limits on exposure rates). With Publication 26 (ICRP, 1977), the emphasis was shifted towards optimisation. Publication 60 (ICRP, 1991) introduced the concept of dose and risk constraints, with the two purposes of increasing equity (i.e. more emphasis on deontological ethics) and providing a practical tool for the control of multiple sources. However, the level of detail concerning constraints in Publication 60 was insufficient. This was remedied in Publication 103 (ICRP, 2007); the purpose and use of constraints is discussed in detail, and hopefully this valuable tool will now be utilised to the full in practical radiological protection.

\subsection{References}

Hansson, S.O., 2007. Ethics and radiation protection. J. Radiol. Prot. 27, 147-156.

IAEA, 1996. International Basic Safety Standards for Protection Against Ionizing Radiation and for the Safety of Radioactive Sources. IAEA Safety Series 115. International Atomic Energy Agency, Vienna. ICRP, 1966. Recommendations of the International Commission on Radiological Protection. ICRP Publication 9. Pergamon Press, Oxford.

ICRP, 1977. Recommendations of the International Commission on Radiological Protection. ICRP Publication 26. Ann. ICRP 1(3).

ICRP, 1991. 1990 Recommendations of the International Commission on Radiological Protection. ICRP Publication 60. Ann. ICRP 21(1-3).

ICRP, 2003. A framework for assessing the impact of ionising radiation on non-human species. ICRP Publication 91. Ann. ICRP 33(3).

ICRP, 2007. The 2007 Recommendations of the International Commission on Radiological Protection. ICRP Publication 103. Ann. ICRP 37(2-4).

UNSCEAR, 2006. Effects of Ionizing Radiation. UNSCEAR 2006 Report. Volume 1. Report to the General Assembly, with Scientific Annexes A and B. UN Sales Publication 08.IX.6. United Nations, Vienna. 
ICRP Publication 109

Main Commission Chairs, Scientific Secretaries, and some other IXRPC/ ICRP personalities

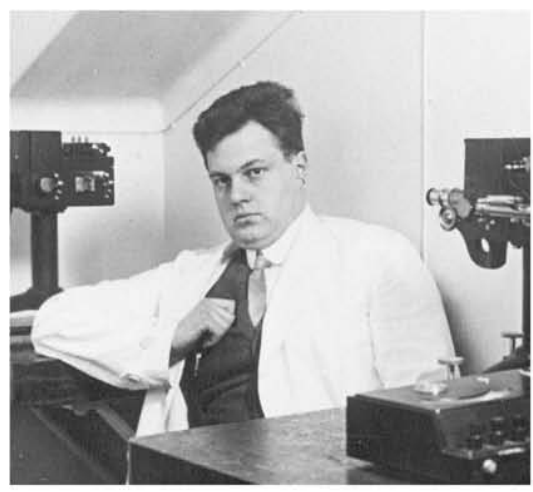

Rolf Sievert, 1923 (Chair 1928-31, 1956-62)

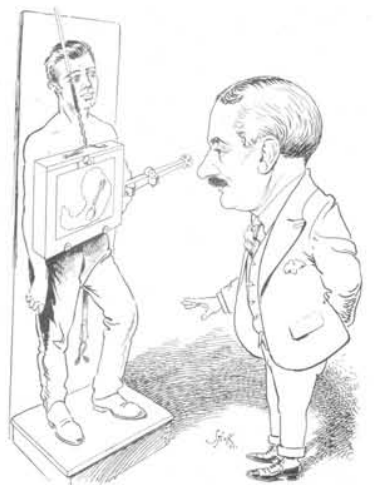

René Ledoux-Lebard (Chair 1931-37)

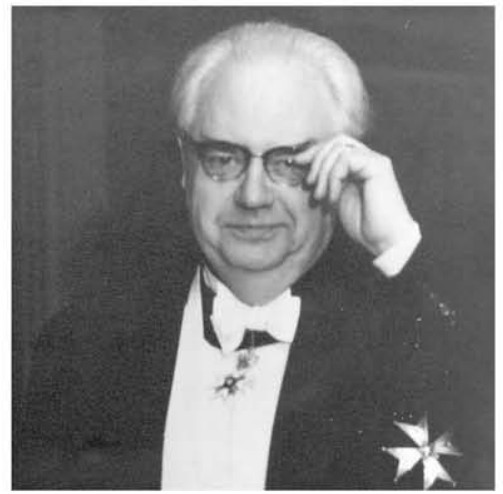

Rolf Sievert 1965 (Chair 1928-31, 1956-62)

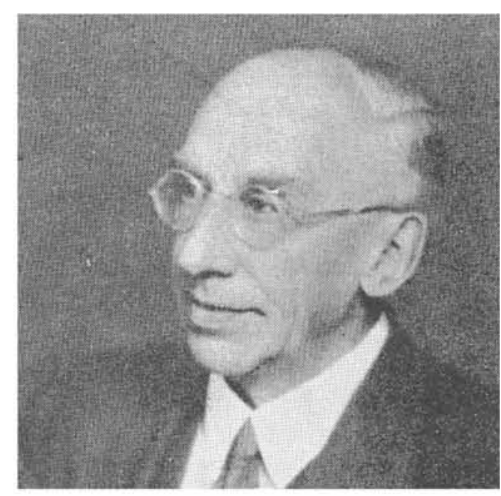

George Kaye (Scientific Secretary 1928)

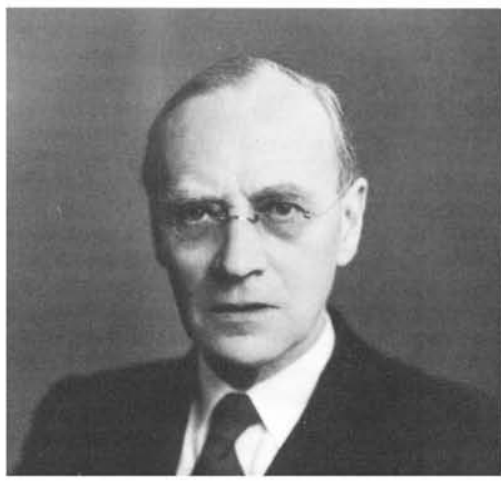

Sir Ernest Rock Carling (Chair 1950-56)

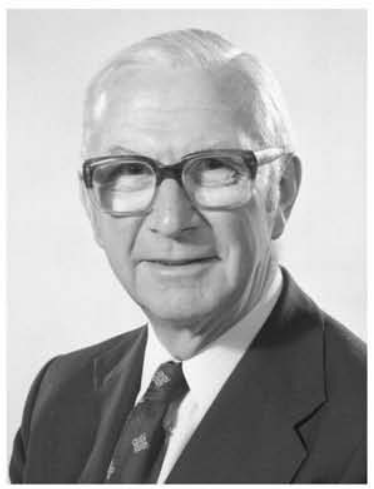

Sir Edward Pochin (Chair 1962-69) 


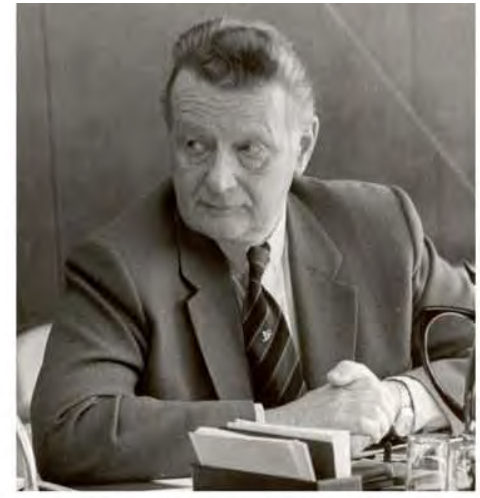

Gordon Stewart (Chair 1969-77)

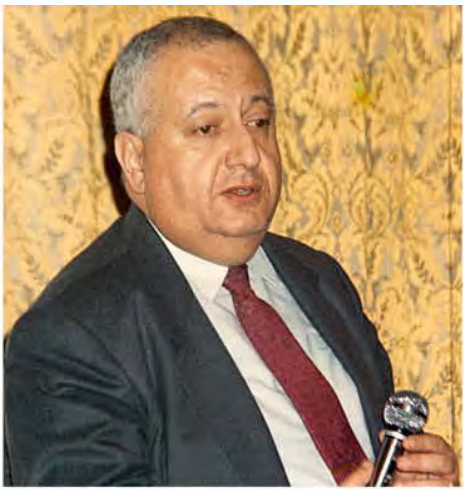

Dan Beninson (Chair 1985-93)

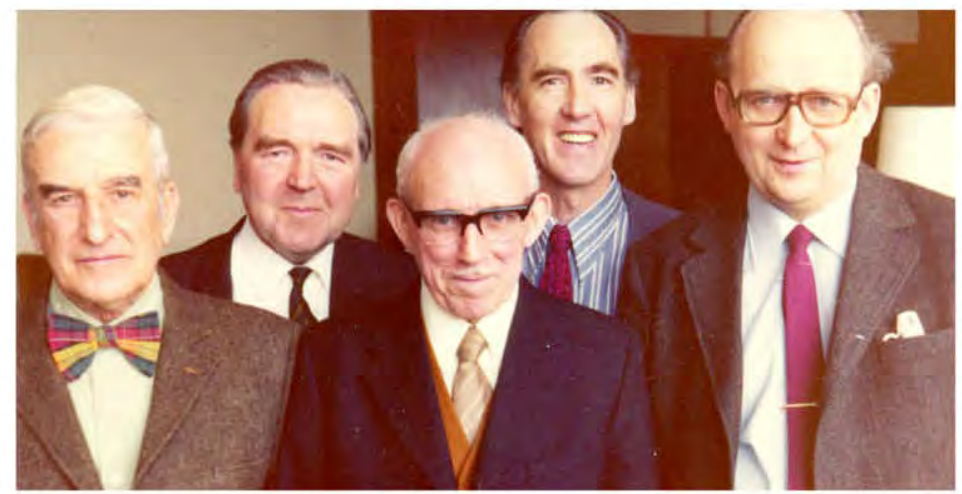

Five Scientific Secretaries in 1975: From left, Lauriston Taylor (1934, 1937, 1947-50; also Chair, 1937-50), Eric Smith (1956; also Committee 3 Chair 1962-65), Walter Binks (195055), David Sowby (1962-85); Bo Lindell (1957-62; also Committee 3 Chair, 1965-77 and Chair, 1977-85)

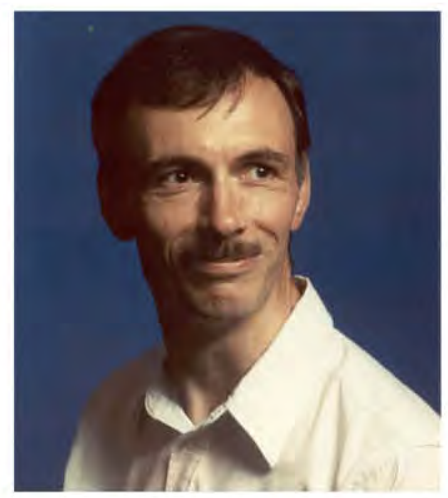

Mike Thorne (Scientific Secretary 1985-87)

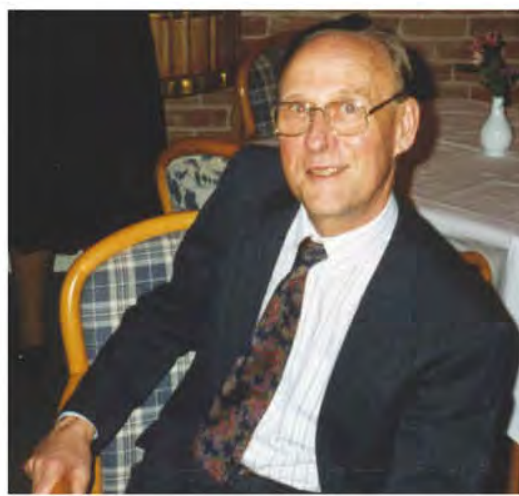

Hylton Smith (Scientific Secretary 1987-97) 
ICRP Publication 109

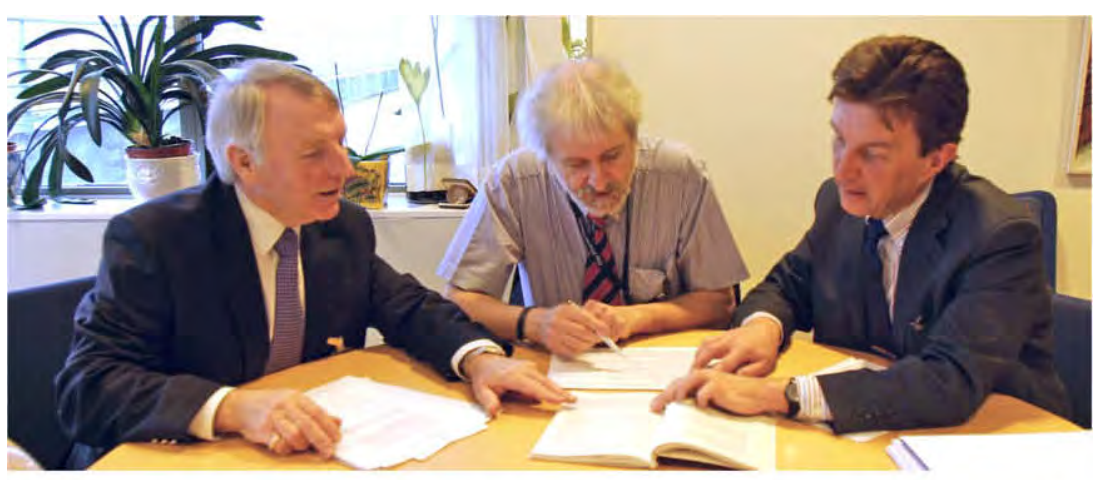

From left: Roger Clarke (Committee 4 Chair 1989-93, Chair 1993-2005), Jack Valentin (Scientific Secretary 1997-2008), Lars-Erik Holm (Chair 2005-2009)

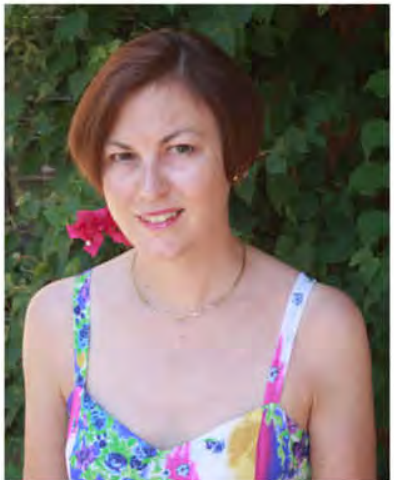

Claire Cousins (Chair 2009- )

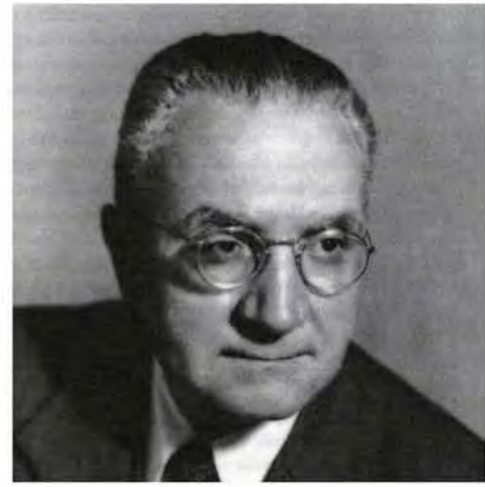

Giaocchino Failla (Sub-Committee I/ Committee I Chair 1950-59)

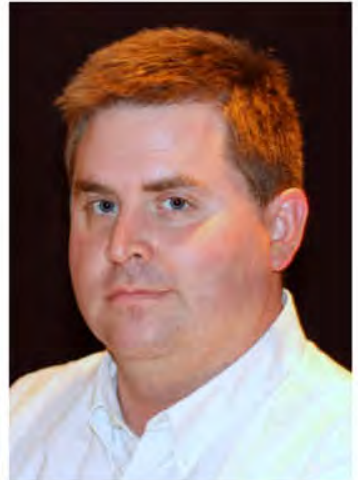

Chris Clement (Scientific Secretary 2009- )

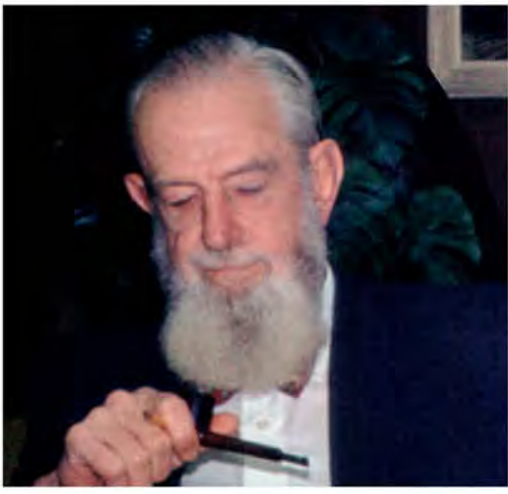

John Loutit (Committee I/ Committee 1 Chair 1959-65) 


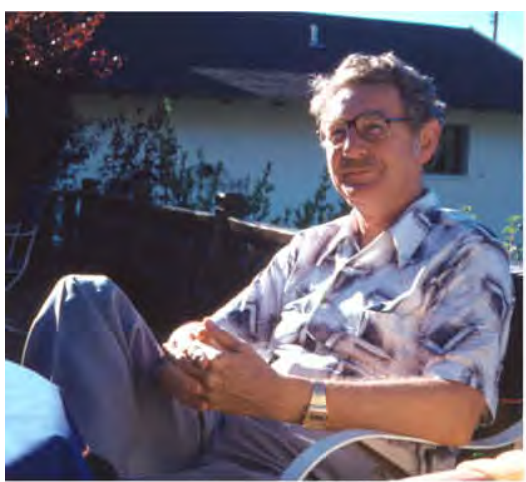

Warren Sinclair (Committee 1 Chair 19852001)

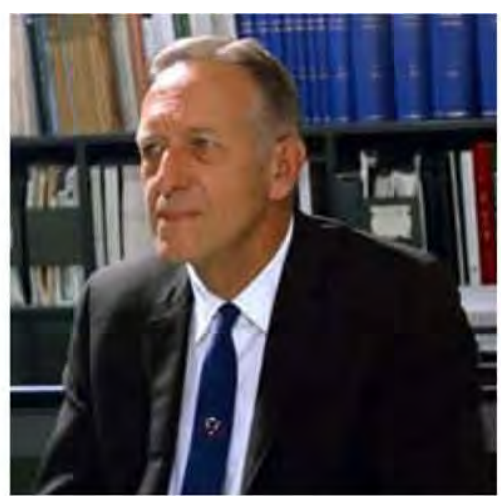

Karl Z. Morgan (Sub-Committee II/ Committee II/ Committee 2 Chair, 1950-73)

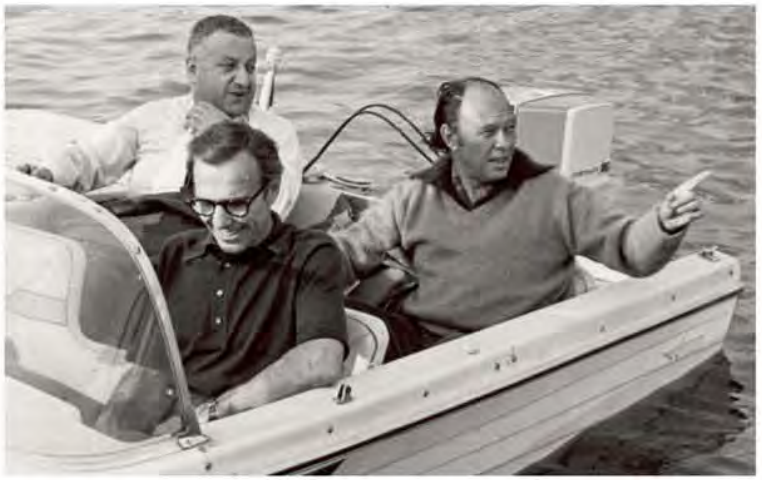

Left front: Arthur Upton (Committee 1 Chair 1973-81), left back: Dan Beninson (Committee

1 Chair 1981-85, Chair 1985-93, Committee 4 Chair 1993-97), right: Henri Jammet

(Committee 4 Chair 1962-85, Committee 3 Chair 1993-96)

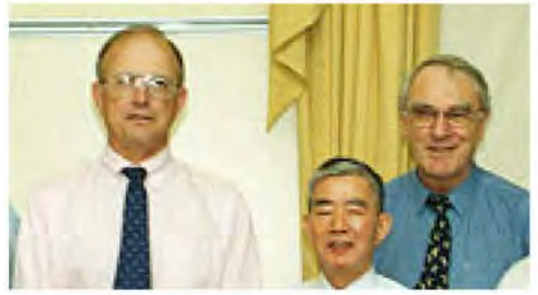

From left: Fred Mettler (Committee 3 Chair, 1996-2005), Hiro Matsudaira (Main

Commission member, 1993-2001), Alex Kaul

(Committee 2 Chair, 1993-2001)

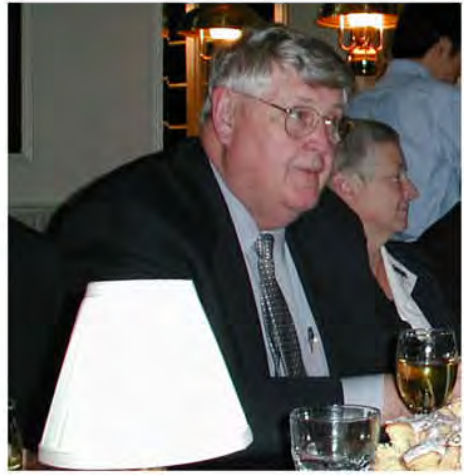

Charlie Meinhold (Committee 3 Chair 197785 , Committee 2 Chair 1985-93) 
ICRP Publication 109

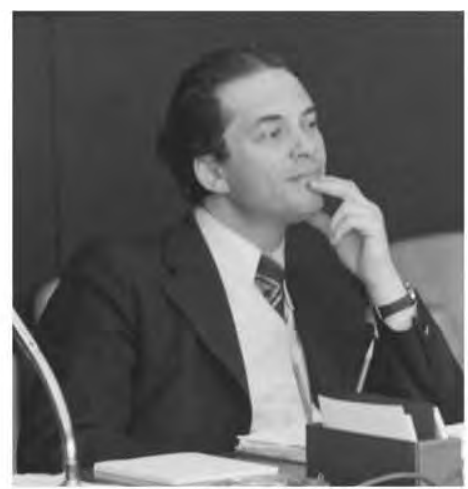

Julian Liniecki (Committee 3 Chair 1985-93)

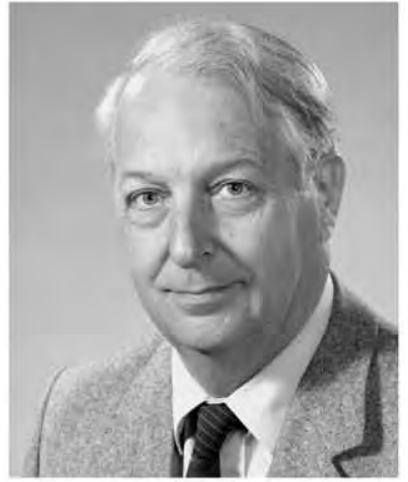

John Dunster (Committee 4 Chair 1985-89)

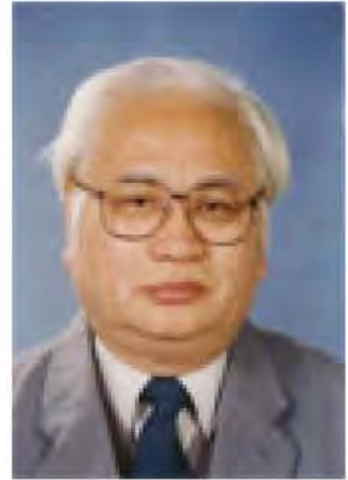

Li Deping (Main Commission member 1985-97)

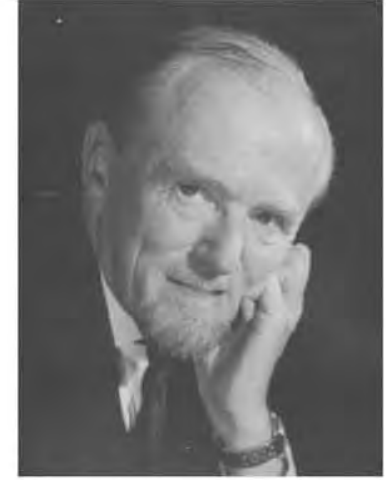

Val Mayneord (Sub-Committee IV/ Committee IV Chair 1950-56)

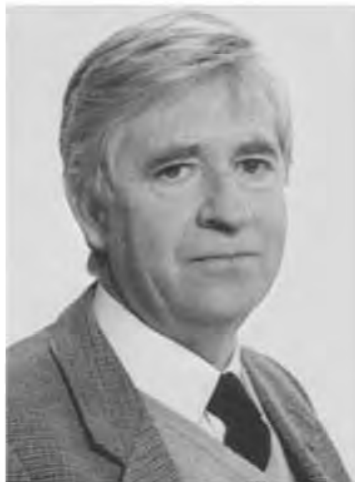

Wolfgang Jacobi (Main Commission member 1977-97)

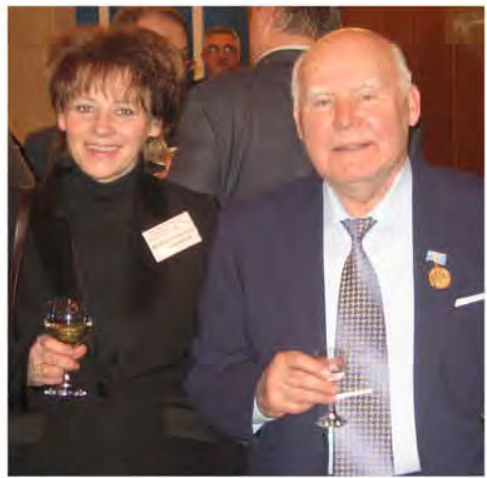

From left: Main Commission members Nataliya Shandala (2005- ) and Leonid Ilyin (1993-2001) 


\section{Corrigendum}

\section{Corrigendum to 'The History of ICRP and the Evolution of its Policies' [Ann. ICRP 39(1)]

\author{
R.H. Clarke, J. Valentin
}

The authors would like to point out that there were errors present in Table 1.3, on page 84 , under 'Committee 1 Chair'.

The error as present is:

1985-2001

2001-2009

2009-

The corrected form is:

1985-1997

1997-2005

2005-

The Publisher and Authors apologize for this error.
Warren K Sinclair, USA Roger Cox, UK

Ohtshura Niwa, Japan

Warren K Sinclair, USA

Roger Cox, UK

Julian Preston, USA 